\title{
Importance of respiratory viruses in calves from family farming dairy herds in the state of São Paulo, Brazil
}

Natália Carrillo Gaetad ${ }^{[a]}$, Bruno Leonardo Mendonça Ribeiro[a], Mário Augusto Reyes Alemán ${ }^{[a]}$, Eduardo Carvalho Marques ${ }^{[a]}$, Eidi Yoshihara ${ }^{[b]}$, Edviges Maristela Pituco[c], Claudia Pestana Ribeiro[c] Adriana Hellmeister de Campos Nogueira ${ }^{[c]}$, Edison Luiz Durigon ${ }^{[d]}$, Lilian Gregory ${ }^{[a]}$

[a] Departamento de Clínica Médica, Faculdade de Medicina Veterinária e Zootecnia, Universidade de São Paulo (USP), São Paulo, SP, Brazil

[b] Agência Paulista de Tecnologia dos Agronegócios, Departamento de Descentralização do Desenvolvimento, Pólo Regional de Desenvolvimento Tecnológico dos Agronegócios da Alta Sorocabana, Presidente Prudente, SP, Brazil

[c] Laboratório de Viroses de Bovídeos, Instituto Biológico de São Paulo, São Paulo, SP, Brazil

[d] Laboratório de Virologia, Instituto de Ciências Biomédicas II, Universidade de São Paulo (USP), São Paulo, SP, Brazil

${ }^{*}$ Corresponding author

e-mail: natalia.gaeta@hotmail.com

\section{Abstract}

Bovine respiratory disease (BRD) is responsible for great economic losses in dairy cattle herds. Respiratory viruses are commonly categorized as primary etiological agents. The present study aimed to detect the presence of antibodies against bovine parainfluenza type 3 virus (BPI-3v), bovine respiratory syncytial virus (BRSV), bovine viral diarrhea virus (BVDV) and bovine herpesvirus type 1 (boHV-1) in healthy and calves showing clinical signs of bovine respiratory disease from family farming dairy herds in Pontal do Paranapanema, state of São Paulo, Brazil. Serum samples were obtained from 42 family farming dairy herds which cows did not receive vaccines against respiratory viruses. Virus-neutralization was performed using 145 serum samples to detected antibodies against BVDV, BoHV-1 and BRSV, and using 88 samples to detected antibodies against BPI-3v. The association between microorganisms, health status and clinical signs of BRD was evaluated. Data were analyzed by Pearson's chi-square test or Fisher's exact test in the form of univariate analysis. Variables with $\mathrm{P}<0.10$ were considered significant. Serum diagnosis revealed $23 \%$ (34/145), 37\% (54/145) and 32\% (46/145) of reactive calves for BVDV, BoHV-1 and BRSV, respectively. Because of the lack of some clinical information, only 123 calves were correctly classified as healthy and BRD calves. No differences between healthy and BRD calves were detected to BVDV $(P=0.982), B o H V-1$ $(\mathrm{P}=0.281)$ and BRSV $(\mathrm{P}=0.485)$. Calves showing antibodies against BVDV and BRSV were numerically increased in BRD calves. The association between the concomitant presence of antibodies against BVDV and 
BRSV and BRD was detected $(\mathrm{P}=0.02)$. Predominance of calves showing titers of antibodies against BoHV-1 and BRSV between 2 and 16, especially BRSV was observed. The highest titers (1024-8192) were noted in calves showing antibodies against BVDV, only. The presence of antibodies against BRSV were associated to normal heart rates $(P=0.02)$, serous nasal discharge $(P=0.02)$, and unilateral airflow $(P=0.06)$. Regarding to BPI-3v, antibodies were detected in $45.45 \%$ (40/88) of samples. Serum reactive samples were detected in both healthy $(46.8 \% ; 22 / 47)$ and BRD calves $(43.9 \% ; 18 / 41)$. With respect to antibody titer, numerical differences were detected between healthy (3\%) and BRD calves (9\%) for titers 128-512 (P > 0.05). Our results demonstrated that respiratory viruses are present in herds from Pontal do Paranapanema and it addresses the need for constant monitoring. It is well known that the studied viruses are important primary agents of BRD, although these viruses predispose to secondary bacterial infection. Some studies also referred the association between respiratory viruses and clinical signs of BRD. To the best of our knowledge, this is the first study that aimed to evaluate the presence of antibodies against respiratory viruses in calves from family farming dairy herds in the state of São Paulo, Brazil. 